にも示される通り, D孔の先 $20 \mathrm{~m}$ ほどの位置に断層が存在してい ることがなんらかの影響をおよぼしているのではないかと考える。 $4 \cdot 2$ ひずみ (応力の計算値)

第 7 図は，びずみセンサー（ C 孔）功得られたびずみ測定值 に, $3 \cdot 2$ で述べた観測方程式を適用して計算した応力の大きさと 方向を示したものである。

この図からセンサー埋設後から掘進が開始される10月16日まで は, 応力の大きさは多少の減少がみられるものの方向はほぼ一定 しており, 安定した応力状態にあると考えられる。ところが掘進 が開始された直後から応力の大きさ, 万向ともに変化しはじめて おりさらに掘進切羽通過前10日（10月31日, 約 $20 \mathrm{~m}$ 手前) ほどか ら水平方向の応力が増加し，11月 9 日で水平方向で約 $124 \mathrm{~kg} / \mathrm{cm}^{2}$, 垂直方向で $5 \mathrm{~kg} / \mathrm{cm}^{2}$ 程の大きさを示している。さらに切羽通過後 15日で急激な応力の減少を示している。この傾向は第 5 図に示さ れる油圧カプセル $\mathrm{A}$ 孔の切羽面通過 $20 \mathrm{~m}$ 手前からの圧力変化傾向 に類似しており，今回使用したびずみセンサーによる盤圧変化計 測が妥当であつたと考えられる。

\section{$4 \cdot 3$ 湧出ガス圧力}

第 8 図は压力センサー（C孔）の計測結果を油圧カプセルの計 測結果と同様な四にしたものであり，絶軸上部に涌出ガス代力下 部に切羽面とセンサーとの距離, 横軸に観測日数をとつている。

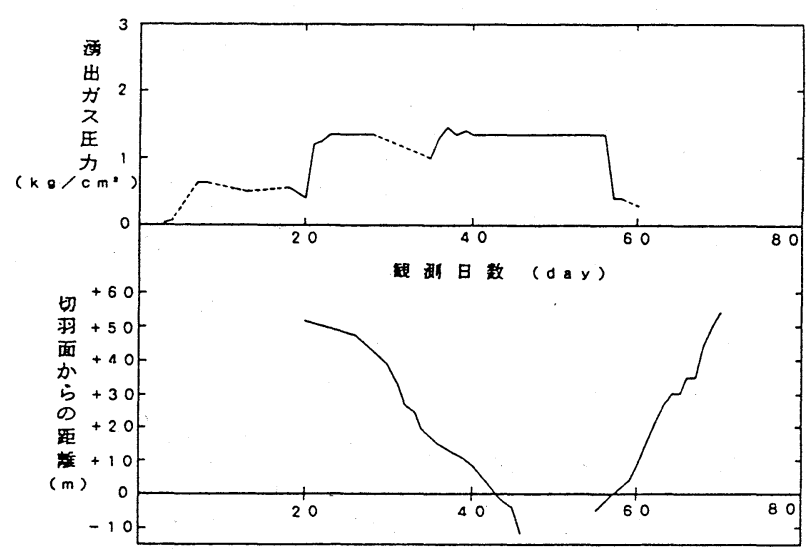

第 8 図
図からガス圧力はセンサー埋設直後から $0.5 \mathrm{~kg} / \mathrm{cm}^{2}$ 程の值を示 し掘進開始と同時に $1.3 \mathrm{~kg} / \mathrm{cm}^{2}$ 程に増加している。さらにこの値 は途中やや減少が見られるものの, 採炭切羽面がセンサー埋設位 置に達するまでほぼ一定値を示しその後急激に減少している。

\section{5. 結 論}

今回の実験により得られた結果は以上であるがこれらの事をま とめると次のようなことが言える。

\section{$5 \cdot 1$ 油圧カプセル}

各炭鉱で多くの使用実績が見られるように盤圧の相対変化を計 測するにはその埋設の容易さ, 計測時のメンテナンスの手軽ささ らに得られたデータの信頼性などたいへん優れていると思われる。 特に今回のようにひずみ計測等を行なう場合にひずみと同時に測 定を行なうことは両者から得られたデータの信頼性を高める目的 で非常に有効である。

\section{$5 \cdot 2$ ひずみセンサー}

ひすずみセンサーから得られたデータを用いて計算された今回の 実験の応力変化傾向は, 油圧カプセル A 孔の圧力変化と大変類似 していた。この事実から今回使用したひずみ計は正常な動作をし ていたと考える。しかし応力の大きさおよび方向については, 解 析の手法などにさらに改善を加える必要があると思われ，今後こ れらの信頼性を高める方法を考えて行きたい。

\section{$5 \cdot 3$ ガス圧カセンサー}

ガス圧については, 当初の予測ではデータが取れるほどの圧力 は生じないのではないかと考えていた。だが計測を開始してみる と意外に圧力の増加がみられ B 孔のセンサーケーブルよりガスが 漏洩する事態となつたため急きよ漏洩を止める試みを行なつたが, 切羽面進行時のデータ収録には間に合わなかつた。これは圧力セ ンサー部の密封が不十分であつたためだと考える。

\section{6. むすび}

今回の実験を実施するにあたつては, 三井石炭鉱業 (株) 砂川鉱 業所の関係者の方々の全面的なご協力を睗わり, さらにセンサー の製作埋設およびデータの解析には北大工学部資源開発工学科岩 石力学講座の皆様にも助力助言をしていただき,ここに記して謝 意を表する次第である。

\title{
〔一 般 講 演〕
}

\section{（16）太平洋炭鉱のオートコントロールホイストによる省人化について}

\section{1. はじめに}

太平洋炭鉱における片盤坑道と採掘現場間の機材運搬は, この 間の坑道が炭層添いに掘削され $0 \sim 6^{\circ}$ の緩傾斜を有し, しかも 小断層等のため傾斜が正負混在することも多く, 採掘現場付近の 舟霟とその他の小型ホイストを含めると $3 \sim 4$ 段の中継となつて いる。

この中で舟虂以外は以下で述べるエンドレス巻等の使用はある ものの, 小型ホイスト巻が 100 台程使用されているのが現状であ り，これに伴う運搬作業に携わる人員は相当な数にのぼつている。 したがつて, これらの運搬に関わる人員の省力・省人化と中継 段数を減少し効率を高めることが当鉱にとつて重要な課題となつ
ている。

そのためこれまで技術開発を進めてきたが，ここに上記課題の 効果を発揮する運搬装置の進展をみることができたので, その概 要を述べ諸賢のご批判を仰ぐ次第である。

\section{2. 運搬方式の変遷}

\section{$2 \cdot 1$ メーンテール巻 (第 1 図)}

この方式は現在当鉱においてはごく一般的に使用されているも のであり, 運搬区間の両端に小型ホイストを配置し, 運転員 2 名 操作員 2 名の計 4 名がこれに携わつている。

しかし両ホイストのローブ速度をほぼ同じくし，かつロープ張 力を適性に維持するには運転員の熟練が必要であり, また誤つた 


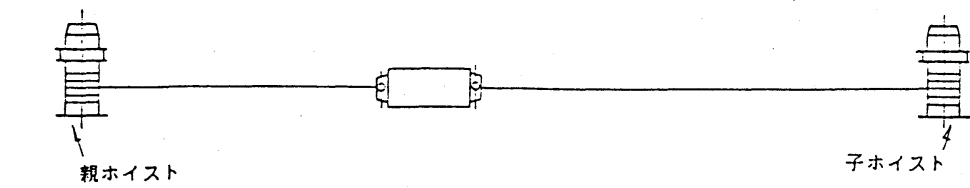

第1図メーンテール

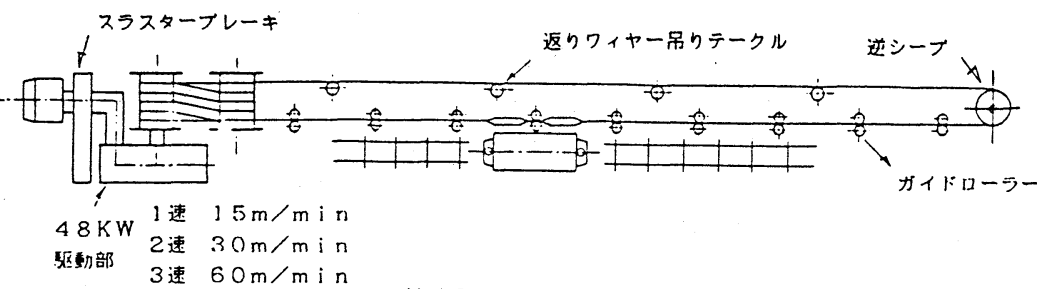

第2図 エンドレス

信号・判断等によりロープに異常張力をかける恐れがある。

$2 \cdot 2$ エンドレス巻（第 2 図）

これはメーンテール巻の省人化と安全性の向上を目的に開発し たものであり，現在 5 台が使用されている。

ラジオコントロールの採用により運転員が不要となり，誤信号 等による不安要素を解消した。

しかし種鉱車の脱線防止のためワイヤロープのガイドローラが 必要であり，特に坑道の曲りが多い場合にはその数も多くなつて 設備費・保全費が意外とかさむことがわかつた。

$2 \cdot 3$ オートコントロールホイスト（第 3 図）

エンドレス巻は種鈗車がワイヤロープに固定されているためワ イヤロープのガイドローラを設置した坑道以外運行できず，した がつて, その区間から分岐する他の卸坑道への運行は不可能である。

この不都合な点と前述のガイドローラの設備・保全費の割高な 点を解消すべく，(財) 石炭技術研究所との共同研究で開発したの がこのオートコントロールホイストである。

この装置は鉱車側のワイヤロープの駆動を三相かご型誘導電動 機に連結した $2 つ の$ 駆動プーリーで行なう。ただし片方の駆動プ ーリーは, 電動クラッチにより電動機の駆動からの切り離しが可 能であり, この場合他の駆動プーリーだけによる鉱車の単独操作 をも可能としており，したがつて，巻立における操車や他の卸坑 道への鈗車の進入を可能にしている。2つのエンドホイストはそ れぞれ直流電動機として働き，一方巻き戻すときは発電機として 働き制動を掛ける。このことにより，駆動プーリーに対するワイ ヤロープの締め付け力をある範囲内に規制し摩擦の発生を防止し

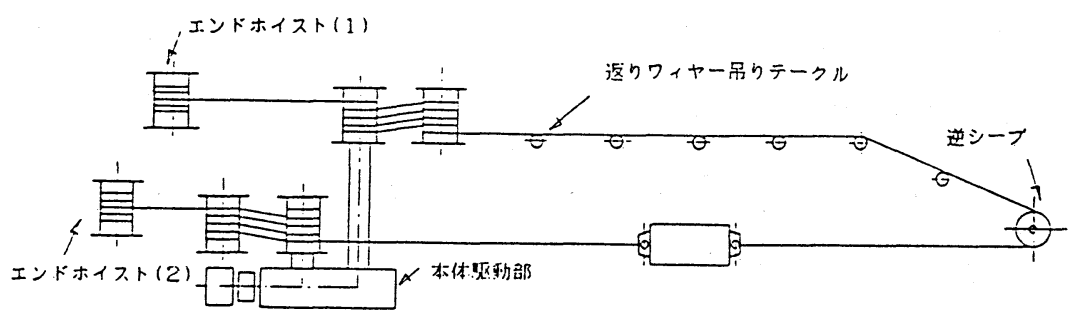

第3図 オートコントロールホイスト

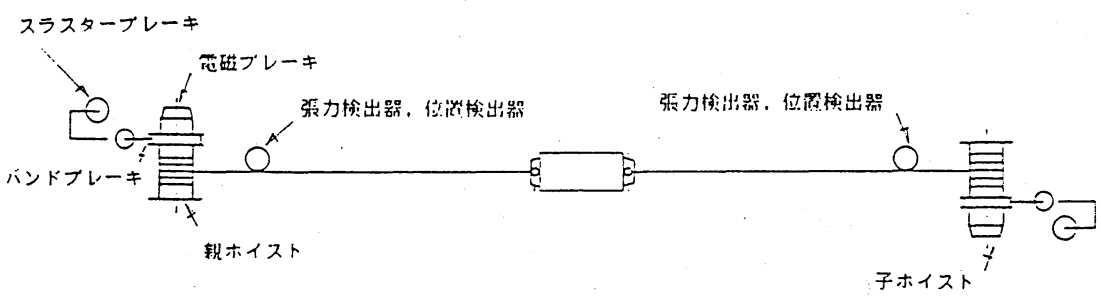

第4図 新型オートコントロールホイスト
ている。

この装置は現在 2 台が本格運転をしてい るが，これまで単独運転による操車の場合

（1）軽荷重の時あるいは緩傾斜部におい てワイヤロープの弛みが少なく操車脱ピン が難しい。

（2）重荷重時にフリクションプーリーの 摩擦係数の増加によりロープ張力が増大する。 等の問題が発生したが, その都度装置の改 善, 使用方法の工夫等により対処してきて いる。

\section{3. 新型オートコントロールホイスト}

\section{$3 \cdot 1$ 概要}

本装置 ( 当鉱では自動ホイストと呼称) は褶曲が多く鉱車の自 重進行ができない坑道で, 従来のホイスト運転を自動化し, ラジ オコントロール装置と組み合わせることによりメーンテール巻の 坑道運搬，分岐運搬の運転を操車員だけで行ないうるものである。 また，本ホイストを片側単線で連続した卸坑道に使用するとラ ジオコントロールにより操車員だけで従来のホイストと同様の運 転を行なうことができる。

$3 \cdot 2$ 設置概要 (第 4 図)

図のように坑道の両端または一端に自動ホイスト 2 台を設置する。

\section{$3 \cdot 3$ 運転概要}

1. 前進の場合, 巻き側ホイストはトライアックによる減電圧 ソフトスタートを行ない, ワイヤロープの巻き取りを始める。巻 き側ホイストは起動時と変速時に速度制御を行なうが，運転中は 全電圧で巻き取りを行なう。

2. 送り側のホイストは回生制動（電気ブレーキ50\%），バン ドブレーキ(機械ブレーキ50\%)による制動の組み合わせにより， ホイスト間のワイヤロープ長が一定になるよう制御する。

3. ワイヤロープ移動量の検出は, ホイスト前部に設置したロ ータリーエンコーダにより行なう。坑道状態によりワイヤロープ 長を一定に保つていると，ワイヤロープ弛みまたは過張が発生す る場合がある。

1）ワイヤロープ弛みが発生した場合，送り側ホイストに より制動を掛けて送り速度を下げる。

2）巻き側，送り側ともに設定張力以上になつた場合，送 り側制動を驰め送り速度を上げる。

ワイヤローブ弛みおよび過張状態 が解消した時点のワイヤロープ長 を記憶し，それ以降の制御基準値 とする。この時送り側制動は，回 生制動(トライアックにより調整), およびバンドブレーキ( パワーシ リンダにより調整）によつて行な う。

4. 停止はパワーシリンダによるバ ンドブレーキで行ならが，停電時はス ラスタブレーキで行なう。さらに補助 としてモータ軸に電磁ブレーキを装備 している。

5. 後進の場合, 巻き側ホイストと 送り側ホイストの動きは逆となる。

6. ホイスト用電動機は極数变換の 3 相誘導電動機を使用し， 2 段階の口

$650<50>$ 
第1表 自動ホイスト主仕様

\begin{tabular}{|c|c|}
\hline ドラム面径 & $\$ 700$ \\
\hline ドラム巾 & 594 \\
\hline ドラムフランジ直佳 & $\$ 1270 \mathrm{~mm}$ \\
\hline ワイャーロープ & $\phi 18 \mathrm{~mm} \times 1400 \mathrm{~mm}$ \\
\hline ロープ涱力 & $3800 \mathrm{kgf}$ \\
\hline ローブ速度 & $50 \mathrm{~m} / \mathrm{min}$ \\
\hline ドラム回転数 & $16.7 / 8.3 \mathrm{rpm}$ \\
\hline 電動機出力 & $37 / 19 \mathrm{KW}$ \\
\hline 極 数 & $6 / 12 P$ \\
\hline 定 & 連続 \\
\hline 電 & $400 \mathrm{~V}$ \\
\hline 回 転 数 & $1000 / 500 \mathrm{rpm}$ \\
\hline
\end{tabular}

ープ速度で運転を行なう。

7. 最大運行距離は $14 \mathrm{~mm}$ ワイヤで $2,000 \mathrm{~m}$ である。

8. 本ホイスト装置の全ての機器は, シーケンスコントローラ

により制御される。

$3 \cdot 4$ ホイスト装置の仕様（第 1 表参照）

$3 \cdot 5$ 保安装置仕様 (第 2 表参照)

4. 結 び
第2 表 自動ホイスト保安装置

\begin{tabular}{|c|c|}
\hline 故障内容 & 事 \\
\hline ア゙レーキ摩耗 & $\begin{array}{l}\text { 連転中、ブレーキ摩耗およびピン切れ等によるブレーキ力低下、 } \\
\text { またはパリーシリンダー異常等を検出する。 }\end{array}$ \\
\hline 異常張力 & 異常張力を検出して停止させる。 \\
\hline ブレ一キ過熱 & ブレーキバンドの異常温度を検出して停止させる。 \\
\hline サーマルリレー & 各電動機の監視をする。 \\
\hline プレーカートリップ & 主回路、補機、操作回路の異常電流を検出して停止させる。 \\
\hline 起動站滞 & 連転開始後10sec以内で規定の速度に達しないと停止させる。 \\
\hline ワイヤー過巻、過差 & $\begin{array}{l}\text { ワイヤーがドラムッバより高くなった時、および地巻2段が } \\
\text { ほとけけた時検出して停止させる。 }\end{array}$ \\
\hline 過速度 & T．G．により規定以上の回転数を検出して停止させる。 \\
\hline 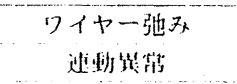 & $\begin{array}{l}\text { 巻き倒のワイヤーの他み過ぎを娭出して停止させる。 } \\
\text { 相手侧の信电等を検坮して停止させる。 }\end{array}$ \\
\hline 登信猉常 & 信号線、受信器の罢常を娭出して停止させる。 \\
\hline
\end{tabular}

これまで当鉱における小型運搬装置の開発の経緯と新型オート コントロールホイストの概要を述べてきたが，省人化，保安面で の向上, 効率化といつた点でこのホイストは当初の目的を達成す ることができた。

しかしこれまで述べてきたように，今後使用を続ける中で改善 の必要な点が多々あると思われるが，鋭意それらを解決してより 完成度の高い運搬装置としていく所存である。

\section{〔記 念 講 演〕}

（17）運搬合理化の一環としての揚炭経路の変更について

三井石炭鉱業 (株) 三池鉱業所

\section{1. 緒言}

当鉱は, 昭和 60 年 12 月, $320 \mathrm{~m}$ 坑道の西 1 ループ〜西 90 ループ 間に大型炭車運搬設備を完成し，翌年 1 月より運行を開始した。 当工事の完成により, 従来 $220 \mathrm{~m}$ 坑道〜 $180 \mathrm{~m}$ 坑道〜西 50 卸 と BC 9 台を経て運炭し, 西 50 ループより大型炭車に積み替え三川 大斜坑 B C より選炭工場へ揚炭していた方式を, 著しく簡素化し 省力化することができた。本報告はこの工事経緯と工事効果につ いて報告するものである。な抗この揚炭経路の変更は，三川鉱 $350 \mathrm{~m}$ 坑道の大型炭車運行区間を, 西90ループまで延長した工事 と相まつて完成したものである。

\section{2. 揚炭経路変更に至る経緯}

当鉱は日鉄鉱業 (株) が昭和 30 年代に開発に着手したが, 出水等 の理由で中断し, その後昭和 48 年より当社の子会社として有明炭 鉣 (株) が再開発を実施した。

昭和 50 年度に着炭，柱房採炭による出炭を開始し，第 1 , 第 2 立坑より $2 \mathrm{~m}^{3}$ 炭車にて揚炭を行なつた。三池選炭工場までの送炭 は, 海上輸送およびトラックによる陸送が計画されたが, 漁業関 係者や地域住民の納得が得られず，結局，有明鉱柵内に約 46 万 $\mathrm{t}$ を貯炭することになつた。

一方坑内経由の揚炭計画も進められ, 昭和 51 年 5 月より当時の 宮浦釷側から $180 \mathrm{~m}$ 坑道, 有明炭鉱側から $220 \mathrm{~m}$ 坑道の掘進が開 始された。この連絡坑道の貫通を受け, 昭和52年 10 月より有明炭 鉱は三井石炭鉱業(株)に合併され，揚炭 BCも $220 \mathrm{~m}$ 坑道〜 180 $\mathrm{m}$ 坑道〜西50卸ルートで連結した。この設備の完成により, それ までの柱房採炭から払採炭も可能となり, 大幅な増産体制が確立さ
れた。

以来約 8 年, 昭和 60 年までの運炭量は 1,000 万 $\mathrm{t}$ に達し, 揚炭 $\mathrm{B} C$ 設備の更新時期を迎え，採掘フィールドも $220 \mathrm{~m}$ レベルから $320 \mathrm{~m}$ レベルへ移行した。一方三川銨では大型炭車運行区間を西 90ループまで延長することになり，これらの要素を考慮し揚炭経 路の変更を計画した。

この計画は三川鉱 $350 \mathrm{~m}$ 坑道と有明鉱 $320 \mathrm{~m}$ 坑道が貫通した昭 和55年に立案されたが，困難な要素が多く着工が遅れ，掘進，拡 大, 覆工, 特免検査, 施設工事等, 大部分の工事を昭和 59 年から 60 年にかけて実施した。昭和 60 年 12 月より大型炭車の試験運行を 開始し, 翌年 1 月より揚炭変更を実施した。

\section{3. 旧揚炭経路}

旧揚炭経路を第 1 図に示す。上層部内, 第 2 上層部内より計 14 台の BCで運ばれた石炭は, No. 8 揚炭 B Cに集約され, $220 \mathrm{~m}$ 坑 道〜 $180 \mathrm{~m}$ 坑道〜西 50 卸と 9 台の揚炭 $\mathrm{BC}$ を経由して西50ループ ポケットに貯えられる。ここで三川鉱の大型炭車に積み込まれ, 三川大斜坑 B C より揚炭される。旧揚炭経路の使用開始以来の実 績は以下の通りである。

\begin{tabular}{|c|c|}
\hline 運転期間 & 昭和 52 年 11 月 14 日 昭和 61 年 1 月 18 日 \\
\hline 主要 B C 総延長 & $\begin{array}{l}8,661 \mathrm{~m} \quad \text { 計 } 23 \text { 台 } \\
\text { (西50ループポケット〜部内入口) }\end{array}$ \\
\hline 主要 $\mathrm{BC}$ 当番人員 & 13 人 $/$ 方 $\times 3=39$ 人 $/$ 日 \\
\hline 総運炭量 & $10,162,810 \mathrm{t}$ \\
\hline 年産最高運炭量 & $\begin{array}{l}1,442,412 \mathrm{t} \\
\text { ( 昭和 } 55 \text { 年 } \cdots \text { 含む貯炭逆送炭) }\end{array}$ \\
\hline 月産最高出炭量 & $143,091 \mathrm{t}$ （昭和57年 3 月） \\
\hline
\end{tabular}

日本鉱業会誌/103 $1196(' 87-10) 651<51>$ 